\title{
Karyological study of some Mediterranean species from Bosnia and Herzegovina, Croatia and Lebanon
}

\begin{abstract}
Pustahija, F., Šolić, E. M. \& Siljak-Yakovlev, S. 2017: Karyological study of some Mediterranean species from Bosnia and Herzegovina, Croatia and Lebanon [In Kamari, G., Blanché, C. \& Siljak-Yakovlev, S. (eds), Mediterranean chromosome data - 27]. - Fl. Medit. 27: 295-301. doi: 10.7320/FlMedit27.295

Chromosome numbers and metaphase plates are given for seven species from Bosnia and Herzegovina (Anacamptis morio, Asphodelus albus, Dactylorhiza maculata, Digitalis grandiflora, Narcissus poeticus, Platanthera bifolia, Polygonatum multiflorum), and one species from Croatia (Narcissus obsoletus) and Lebanon (Narcissus tazetta). Chromosome counts and genome sizes are discussed.
\end{abstract}

1926. Anacamptis morio (L.) R. M. Bateman, Pridgeon \& M. W. Chase $-2 n=36$ (Fig. 1a).

BH: Mliništa, Glamoč, limestones, $44^{\circ} 14^{\prime} 04,65^{\prime \prime} \mathrm{N}, 16^{\circ} 50^{\prime} 00,72$ ” E, 1220 m a.s.1., 10 May 2008, private herbarium of F.P.

Anacamptis morio (L.) R. M. Bateman, Pridgeon \& M. W. Chase is a bulbous herbaceous perennial plant, native to western Eurasia, ranging from Europe to Iran.

The chromosome number $2 n=36$ counted here agrees with some previous reports, since this species has a variable number of chromosome counts $2 n=20,32,36$ and 38 (Fedorov 1969; IPCN 1979). Siljak-Yakovlev \& al. (2010) published the genome size of 2C $=19.27 \mathrm{pg}$ for this species as Orchis morio L. from other BH population.

1927. Asphodelus albus Mill. $-2 n=28$ (Fig. 1b).

BH: Galečić, Livno, limestones, $43^{\circ} 47^{\prime} 18,55^{\prime}$ N, $17^{\circ} 10^{\prime} 14,86^{\prime \prime}$ E, $1071 \mathrm{~m}$ a.s.1., 19 May 2008, private herbarium of F.P.

Asphodelus albus Mill. is a herbaceous perennial plant, native to the Mediterranean area.

The diploid chromosome number $2 n=28$ confirms previous reports of Capineri \& al. (1978), Díaz Lifante (1996) and Siljak-Yakovlev \& al. (2010), but differs from $2 n=26$ (Fedorov 1969), $2 n=56$ (Fedorov 1969; Guillén \& Laínz 1997) and $2 n=84$ (Guillén \& Laínz 1997). The measured genome size for $2 n=28$ is $2 \mathrm{C}=7.25 \mathrm{pg}$ (Siljak-Yakovlev \& al. 2010). 


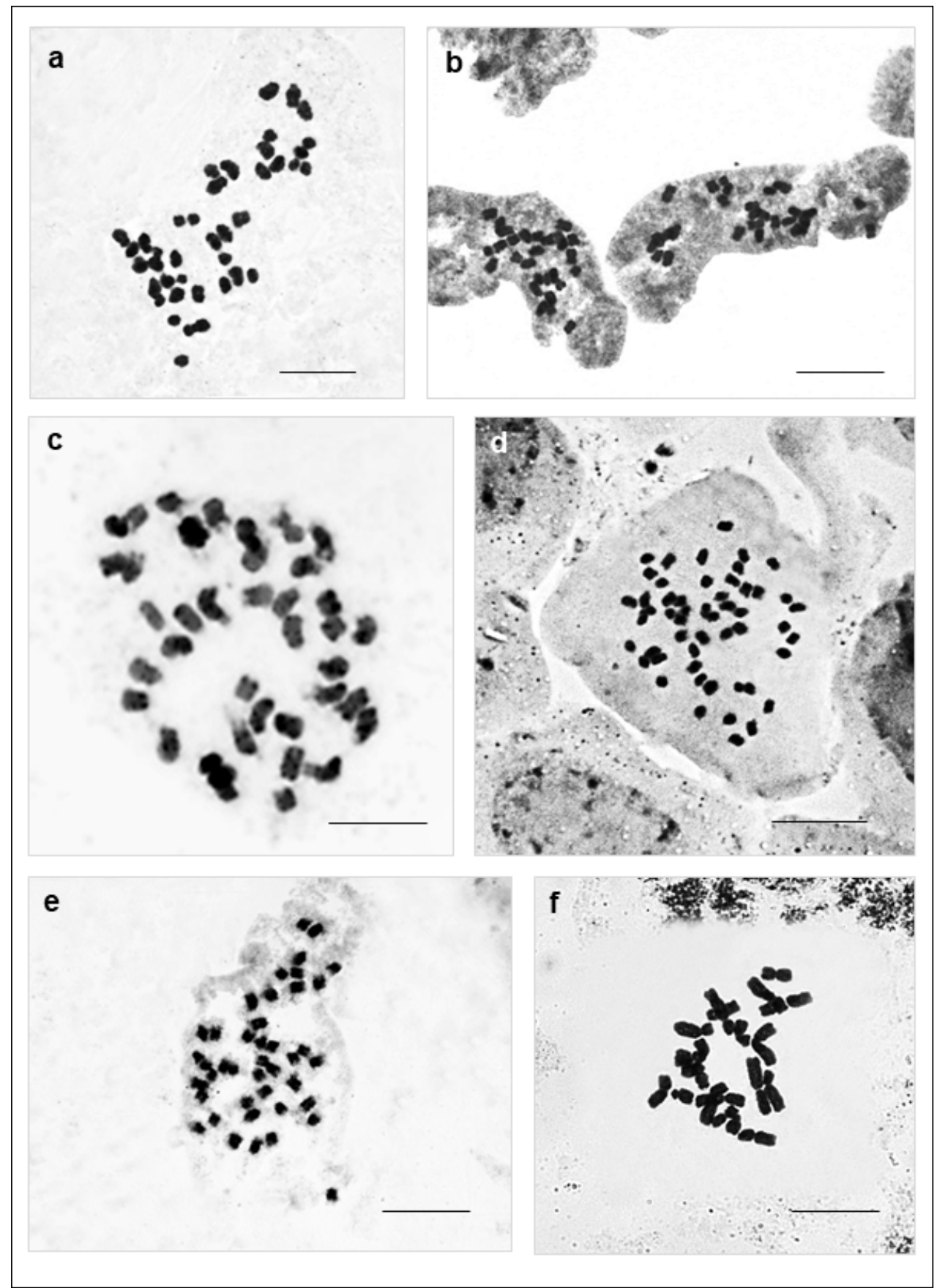

Fig. 1. Mitotic methaphase plates of: a, Anacamptis morio, $2 n=36 ; \mathbf{b}$, Asphodelus albus, $2 n=28$; $\mathbf{c}$, Dactylorhiza maculata, $2 n=40 ; \mathbf{d}$, Digitalis grandiflora, $2 n=56$; e, Platanthera bifolia, $2 n=42$; $\mathbf{f}$, Polygonatum odoratum, $2 n=20$. - Scale bars $=10 \mu \mathrm{m}$. 
1928. Dactylorhiza maculata (L.) Soó $-2 n=40$ (Fig. 1c).

BH: Katranica, Muške Vode, Kladanj, serpentine, 44 ${ }^{\circ} 14^{\prime} 11,64^{\prime \prime}$ N, $18^{\circ} 34^{\prime} 17,87^{\prime \prime}$ E, 825 $\mathrm{m}$ a.s.1., 06 May 2008, private herbarium of F.P.

Dactylorhiza maculata (L.) Soó is a herbaceous perennial plant, native to Europe, but also found in Algeria, Morocco, western Siberia and Canada.

Different chromosome numbers $(2 n=40,40-41,60,78$ and 80$)$ are given in the literature for this species (IPCN 1979; Bertolini \& al. 2000; Aagaard \& al. 2005; SiljakYakovlev \& al. 2010), and our count of $2 n=40$ is in accordance with previous reports for diploids. Siljak-Yakovlev \& al. (2010) estimated the genome size for diploids $(2 \mathrm{C}=6.80$ pg) and Aagaard \& al. (2005) for tetraploids $(2 \mathrm{C}=11.32 \mathrm{pg})$.

1929. Digitalis grandiflora Mill. $-2 n=56$ (Fig. 1d).

BH Papratnica, Žepče, serpentine, $44^{\circ} 26^{\prime} 13,33$ ' N, $17^{\circ} 58^{\prime} 39,33$ ' E, 333 m a.s.1., 29 Jun 2008, private herbarium of F.P.

Digitalis grandiflora Mill. is a herbaceous biennial or perennial plant, native to southern Europe and Asia.

The diploid chromosome number $2 n=56$ is stable for the species and coincides with data obtained by different authors (Fedorov 1969; IPCN 1979; Vidic \& al. 2009; Temsch $\&$ al. 2010; Pustahija \& al. 2013). Estimated genome sizes for the species are $2 \mathrm{C}=2.30$ pg (Temsch \& al. 2010), 2.56 pg (Pustahija \& al. 2013) and 2.60 pg (Vidic \& al. 2009).

1930. Narcissus obsoletus (Haw.) Spach $-2 n=30$ (Fig. 2a).

Ct: Lovište, Pelješac Peninsula, limestones, $43^{\circ} 02^{\prime} 47,32^{\prime \prime} \mathrm{N}, 17^{\circ} 00^{\prime} 10,33^{\prime \prime} \mathrm{E}, 12 \mathrm{~m}$ a.s.1., 19 Oct 2008 , private herbarium of E.M.S.

Narcissus obsoletus (Haw.) Spach is a bulbous herbaceous perennial plant, native to the Mediterranean littoral with geographical distribution from northern Africa and the Iberian Peninsula to Israel on east.

This is the first finding of this species for the Croatian flora identified also thanks to count of chromosome number $2 n=30$ and analysis of chromosome complement, which is in agreement with data obtained by Díaz Lifante \& al. (2009). Siljak-Yakovlev \& al. (2010) published its genome size but as $N$. serotinus L. $2 \mathrm{C}=43.85 \mathrm{pg}$.

1931. Narcissus poeticus L. $-2 n=14,14+1-2 B s \& 21+0-3$ Bs (Figs $2 b$, c \& d).

BH: Katranica, Muške Vode, Kladanj, serpentine, 44 14' 11,64” N, 18 34’ 17,87’ E, 825 $\mathrm{m}$ a.s.1., 06 May 2008, private herbarium of F.P. 


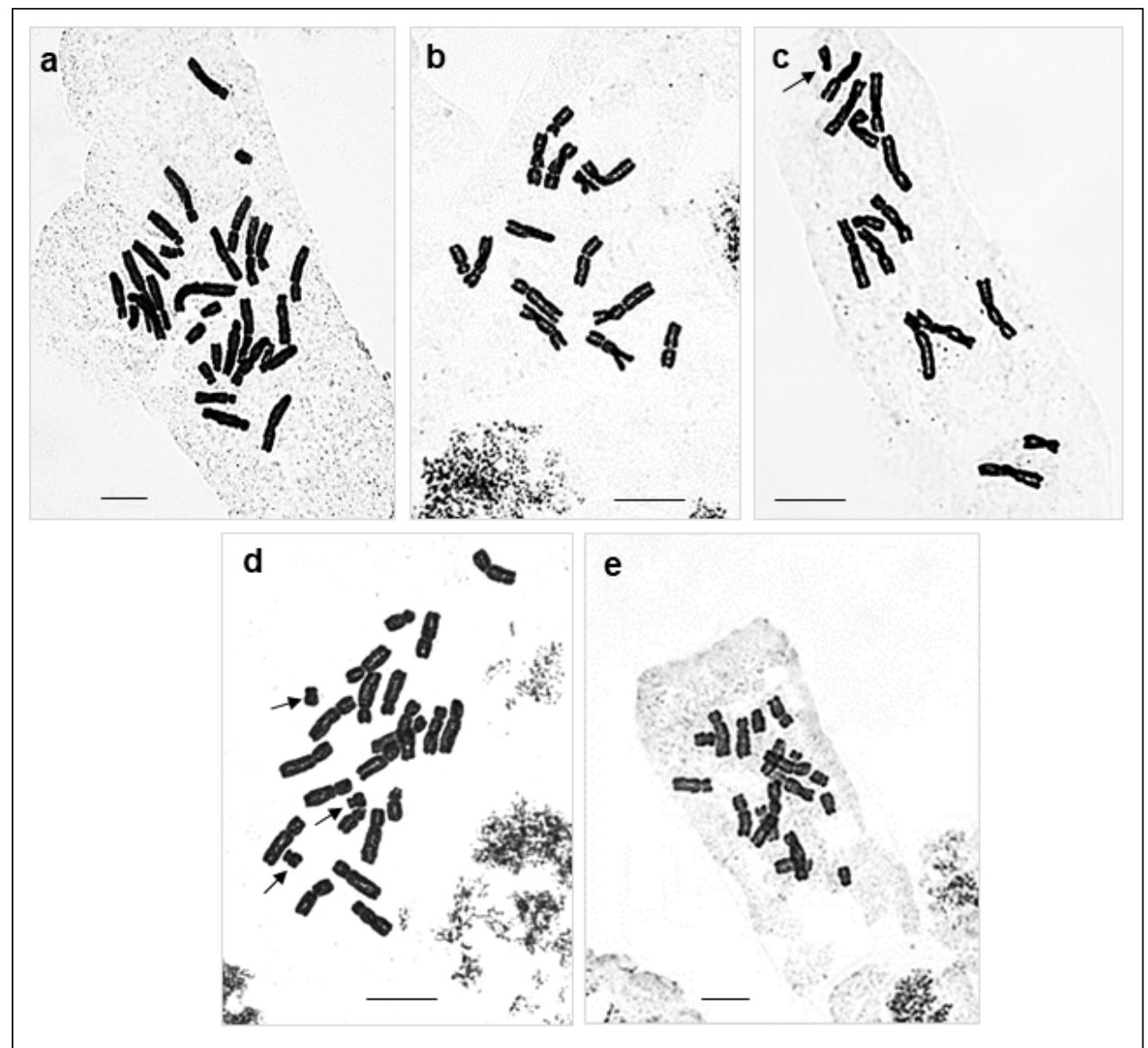

Fig. 2. Mitotic methaphase plates of Narcissus: a, $N$. obsoletus, $2 n=30 ; \mathbf{b}, N$. poeticus, $2 n=14$ (population Katranica); c, $N$. poeticus, $2 n=14+1 \mathrm{~B}$ (population Donje Peulje); d, $N$. poeticus, $2 n=$ $21+3 \mathrm{Bs}$ (population Avtovac); e, $N$. tazetta, $2 n=18$. - Arrows indicate the B chromosomes. Scale bars $=10 \mu \mathrm{m}$.

- Donje Peulje, Bosansko Grahovo, limestone, $44^{\circ} 08^{\prime} 42,81$ ' N, $16^{\circ} 27^{\prime} 48,12$ " E, 810 m a.s.1., 10 May 2008, private herbarium of F.P.

- Avtovac, Gatačko Polje, Gacko, limestones, 4307' 49,40” N, 18 34'01,46” E, 949 $\mathrm{m}$ a.s.1., 13 May 2008, private herbarium of F.P.

Narcissus poeticus L. is a bulbous herbaceous perennial plant, native to central and southern Europe and cultivated, as a horticultural species, throughout the world.

The diploid chromosome number $2 n=14+0-2 \mathrm{Bs}$ is reported by several authors (Fedorov 1969; IPCN 1979; Zonneveld 2008; Siljak-Yakovlev \& al. 2010; Pustahija \& al. 2013) as well as triploid chromosome number $2 n=21$ (Fedorov 1969; IPCN 1979; 
Brandham \& Kirton 1987; Siljak-Yakovlev \& al. 2010). Here we confirm chromosome numbers of diploids $2 n=14+0$-2Bs and triploids $2 n=21+0$-3Bs. Genome sizes of diploids were 24.33 (Siljak-Yakovlev \& al. 2010), 26.00 (Zonneveld 2008), 27.50 pg (Olszewska \& Osiecka 1982), and for triploids 2C $=34.55 \mathrm{pg}$ (Siljak-Yakovlev \& al. 2010).

1932. Narcissus tazetta L. $-2 n=18$ (Fig. 2e).

Le: El Aleli, limestones, 30 m a.s.1., 13 Apr 2012, leg. M. Bou Dagher-Kharrat s.n.

Narcissus tazetta L. is a bulbous herbaceous perennial and ornamental plant, native to the Mediterranean region from Portugal to Turkey, but widespread all over the world.

In the literature, very diverse reports are present for this species in relation to its chromosome number: $2 n=14,20,21,22,24,28,30$ and 32 (Fedorov 1969; IPCN 1979; Brandham \& Kirton 1987; Zonneveld 2008; Bennett \& Leitch 2012; Boukhenane \& al. 2015). Here we present, for the first time, the chromosome number $2 n=18$ that we found in one Lebanon population. This finding merites to be deepened. Three different genome sizes are published for this species $2 \mathrm{C}=25 \mathrm{pg}$ (Bou Dagher-Kharrat \& al. 2013), 2C= 30.30 (Zonneveld 2008), 39.54 pg (Vesely \& al. 2011).

1933. Platanthera bifolia (L.) Rich. $-2 n=42$ (Fig. 1e).

BH: Katranica, Muške Vode, Kladanj, serpentine, 44 14 ' 11,64” N, $18^{\circ} 34^{\prime} 17,87^{\prime \prime}$ E, $825 \mathrm{~m}$ a.s.1., 06 May 2008, private herbarium of F.P.

Platanthera bifolia (L.) Rich. is a tuberculous herbaceous perennial plant, native to Europe, Asia-Temperate, Algeria and Tunisia.

The diploid chromosome number $2 n=42$ is in accordance with the most aviable literature data (Fedorov 1969; IPCN 1979; Siljak-Yakovlev \& al. 2010) but not with $2 n=16$ and 40 (IPCN 1979). Estimated amounts of nuclear DNA were $2 \mathrm{C}=13.74$ and $19.89 \mathrm{pg}$ by Siljak-Yakovlev \& al. 2010 and Vesely \& al. 2011, respectively.

1934. Polygonatum odoratum (Mill.) Druce $-2 n=20$ (Fig. 1f).

BH: Katranica, Muške Vode, Kladanj, serpentine, 44 ${ }^{\circ} 14^{\prime} 11,64^{\prime \prime}$ N, 18 34’ 17,87' E, 825 $\mathrm{m}$ a.s.1., 06 May 2008, private herbarium of F.P.

Polygonatum odoratum (Mill.) Druce is a rhizomatous herbaceous perennial plant, native to Europe, Caucasus, Siberia, Russian Far East, China, Mongolia, Korea and Japan.

A very diverse chromosome number for the species can be found in the literature $2 n=$ 16, 18, 20, 20+0-2Bs, 22, 24, 30 and 40 (Fedorov 1969; IPCN 1979; Siljak-Yakovlev \& al. 2010 ), where the $2 n=20$ that we found is the most common. Measured genome sizes are 
$2 \mathrm{C}=19.66$ (Siljak-Yakovlev \& al. 2010), 20.04 (Vesely \& al. 2011) and $23.10 \mathrm{pg}$ (Zonneveld \& al. 2005).

\section{Acknowledgments}

The authors are grateful to M. Bou Dagher-Kharrat for collecting Narcissus tazetta bulbs.

\section{References}

Aagaard, S. M. D., Sastad, S. M., Greilhuber, J. \& Moen, A. 2005: A secondary hybrid zone between diploid Dactylorhiza incarnata ssp. cruenta and allotetraploid D. lapponica (Orchidaceae). Heredity 94: 488-496.

Bennett, M. D. \& Leitch, I. J. 2012: Angiosperm DNA C-values database (release 8.0, Dec. 2012). - http://www.kew.org/cvalues/ [Last accessed 17.11.2017]

Bertolini, V., Del Prete, C. \& Garbari, F. 2000: Karyological and biometrical studies on some species of the genus Dactylorhiza Necker ex Nevski sec. Dactylorhiza (Orchidaceae) of Central-nothern Italy. - Portugaliae Acta Biol. 19: 249-265.

Bou Dagher-Kharrat, M., Abdel-Samad, N., Douaihy, B., Bourge, M., Fridlender, A., SiljakYakovlev, S. \& Brown, S. C. 2013: Nuclear DNA C-values for biodiversity screening: Case of the Lebanese flora. - Pl. Biosyst. 147(4): 1228-1237. doi: 10.1080/11263504.2013.861530

Boukhenane, M., Khalfallah, N., Pustahija, F. \& Siljak-Yakovlev, S. 2015: Cytogenetic characterization of six populations of Narcissus tazetta L. (Amaryllidaceae) from western Mediterranean. - Int. J. Adv. Res. 3(11): 1538-1546.

Brandham, P. E. \& Kirton, P. R. 1987: The chromosomes of species, hybrids and cultivars of Narcissus L. (Amaryllidaceae). - Kew Bull. 42(1): 65-102.

Capineri, R., D’Amato, G. \& Marchi, P. 1978: Numeri cromosomici per la Flora Italiana: 534-583. - Inform. Bot. Ital. 10: 421-465.

Díaz Lifante, Z. 1996: A karyological study of Asphodelus L. (Asphodelaceae) from the Western Mediterranean. - Bot. J. Linn. Soc. 121: 285-344.

-, Camacho, C. A., Viruel, J. \& Caballero, A. C. 2009: The allopolyploid origin of Narcissus obsoletus (Alliaceae): identification of parental genomes by karyotype characterization and genomic in situ hybridization. - Bot. J. Linn. Soc. 159: 477-498.

Fedorov, A. A. 1969: Chromosome numbers of flowering plants. Academy of sciences of the USSR, V. L. Komarov Botanical Institute, Nauka. - Leningrad.

Guillén, A. \& Laínz, M. 1997: Algo sobre algún Asphodelus de los que alcanzan las costas atlánticas. - Anales Jard. Bot. Madrid 55(2): 482-484.

IPCN. Index to plant chromosome numbers. 1979- : Goldblatt P. \& Johnson D.E. (Eds). - Missouri Botanical Garden, St. Louis. http://www.tropicos.org [Last accessed 20.11.2017]

Olszewska, M. J. \& Osiecka, R. 1982: Relationship between 2C DNA content, life-cycle, systematic position \& level of DNA endoreplication in parenchyma cell nuclei during root growth and differentiation in some monocots. - Biochem. Physiol. Pflanz. 177: 319-336.

Pustahija, F., Brown, S. C., Bogunić, F., Bašić, N., Muratović, E., Ollier, S., Hidalgo, O., Bourge, M., Stevanović, V. \& Siljak-Yakovlev, S. 2013: Small genomes dominate in plants growing on serpentine soils in West Balkans, an exhaustive study of 8 habitats covering 308 taxa. - Pl. Soil 373: 427-453. doi: 10.1007/s11104-013-1794-x

Siljak-Yakovlev, S., Pustahija, F., Šolić, E. M., Bogunić, F., Muratović, E., Bašić, N., Catrice, O. \& Brown, S. C. 2010: Towards a genome size and chromosome number database of Balkan flora: C-values in 343 taxa with novel values for 242. - Adv. Sci. Lett (U.S.A.) 3(2): 190-213. 
Temsch, E. M., Temsch, W., Ehrendorfer-Schratt, L. \& Greilhuber, J. 2010: Heavy metal pollution, selection, and genome size: The species of the Žerjav study revisited with flow cytometry. J. Bot. 2010: Article ID 596542, 11 Pp. doi: 10.1155/2010/596542

Vesely, P., Bures, P., Smarda, P. \& Pavlicek, T. 2011: Genome size and DNA base composition of geophytes: the mirror of phenology and ecology? - Ann. Bot. 109: 65-75.

Vidic, T., Greilhuber, J., Vilhar, B. \& Dermastia, M. 2009: Selective significance of genome size in a plant community with heavy metal pollution. - Ecol. Appl. 19: 1515-1521.

Zonneveld, B. J. M. 2008: The systematic value of nuclear DNA content for all species of Narcissus L. (Amaryllidaceae). - Pl. Syst. Evol. 275: 109-132.

-, Leitch, I. J. \& Bennett, M. D. 2005: First nuclear DNA amounts in more than 300 angiosperms. - Ann. Bot. 96(2): 229-244.

Addresses of the authors:

Pustahija, Fatima $^{1}$, Šolić, Edita Marija ${ }^{2} \&$ Siljak-Yakovlev, Sonja ${ }^{3}$,

${ }^{1}$ Faculty of Forestry, University of Sarajevo, Zagrebačka 20, Sarajevo, Bosnia and Herzegovina. E-mail: f.pustahija@sfsa.unsa.ba

${ }^{2}$ Institute "Mountain and Sea", Franjevački put 1, H-21300 Makarska, Croatia. E-mail: meditasolic@gmail.com

${ }^{3}$ Ecologie, Systématique et Evolution, Département "Evolution des angiospermes", Univ. Paris-Sud, CNRS, AgroParisTech, Université Paris-Saclay, Bât 360, 91405

Orsay cedex, France. E-mail: sonia.yakovlev@u-psud.fr 